\title{
A Canadian Perspective on the Subjective Component of the Bipartite Test for "Persecution": Time for Re-evaluation
}

\author{
Michael Bossin and Laila Demirdache
}

\begin{abstract}
Canadian decision makers refer so regularly to the bipartite nature of the test for persecution in refugee claims that one rarely gives the matter a second thought. After all, the Supreme Court of Canada in Ward clearly affirmed that a refugee claimant must subjectively fear persecution, and this fear must be wellfounded in an objective sense.

In this article, the authors focus on the meaning and validity of the subjective aspect of the bipartite test. It is especially appropriate to do so at this time, given the introduction of the term "person in need of protection" in section 97 of the Immigration and Refugee Protection Act, and recent Federal Court decisions holding that the subjective fear is not a requirement in section 97 cases.

Looking at the issue of subjective fear from historical, psychological, and legal perspectives, the authors argue: (a) that the drafters of the UN Convention never intended claimants to be "subjectively afraid" in order to qualify for protection; (b) determining an asylum seeker's state of mind presents a minefield of potential problems for decision makers; and (c) given the new IRPA provisions dealing with persons in need of protection, the question is not whether there is a bipartite test for determining well-founded fear, but whether, indeed, there ought to be such a test.
\end{abstract}

\begin{abstract}
Résumé
Les décisionnaires Canadiens font si souvent allusion au caractère bipartite du test de la persécution dans les cas de revendications du statut de réfugié que l'on ne s'arrête presque jamais pour reconsidérer la chose. Après tout, n'est-il pas vrai que la Cour suprême du Canada a affirmé très clairement, dans le cas de Ward, qu'un revendicateur doit avoir une crainte subjective de la persécution, et que cette crainte doit être bien-fondée de façon objective?

Dans cet article, les auteurs se penchent sur le sens à donner à l'aspect subjectif du test bipartite et à sa validité. Il est tout spécialement pertinent de poser ces questions dans les circonstances présentes, étant donné que le terme "personne à protéger » a été inclus à l'article 97 de la Loi sur l'immigration et la protection des réfugiés, et au vu des décisions récentes de la Cour fédérale déclarant que la peur subjective n'est pas une condition requise dans les cas visés par l'article 97.

Examinant la question de la peur subjective du point de vue historique, psychologique et légal, les auteurs soutiennent que: (a) les auteurs de la Convention des $\mathrm{Na}$ tions Unies n'avaient jamais voulu dire que les revendicateurs devaient " avoir une crainte subjective" pour être qualifiés pour la protection; (b) essayer de déterminer l'état d'esprit d'un demandeur du droit d'asile est un exercice truffé d'embûches pour les décisionnaires ; et (c) vu les dispositions récentes de la LIPR concernant les personnes ayant un besoin de protection, la vraie question n'est pas de savoir s'il existe un test bipartite pour déterminer la peur bien-fondée, mais plutôt si un tel test doit exister.
\end{abstract}




\section{Introduction}

I $\mathrm{n}$ a recent decision, the Refugee Protection Division (RPD) of the Immigration and Refugee Board (IRB) accepted that a young, female claimant from Estonia had been the victim of trafficking. ${ }^{1}$ She had been tricked into going to Italy where she thought she would find work as a domestic. Instead, her testimony was that upon arrival in Italy, she was taken and held against her will by a group of men involved in organized criminal activity. The RPD accepted the claimant's allegation that she was forced into prostitution in Italy. ${ }^{2}$ It accepted "that the claimant was greatly traumatized by this prostitution ring" ${ }^{3}$ It also accepted that she had "clearly run afoul of a group of criminals in Estonia," after she escaped from her captors in Italy and returned home. ${ }^{4}$

In a report filed at the claimant's hearing, a clinical psychologist stated that the claimant "reported a constellation of psychological and somatic symptoms that are entirely consistent with individuals who have experienced severe psychological stressors, such as forced confinement, repeated rapes, and forced prostitution." ${ }^{\prime 5}$ According to the psychological report, "[d]iagnostically, [this claimant] meets all the criteria for Post-Traumatic Stress Disorder of chronic duration (i.e., more than three months) with depressed mood as outlined in the Diagnostic and Statistical Manual of Mental Disorders (DSM-IV revised)" (emphasis in the original). ${ }^{6}$ Among the symptoms exhibited by this claimant were: recurrent nightmares; intrusive thoughts; significant emotional distress when exposed to stimuli that remind her of the traumatic events; sleep difficulties; hyper-vigilance; irritability; interpersonal distrust; and social isolation/withdrawal. ${ }^{7}$

As her lawyers, we had come to know this woman well over a period of more than two years. In preparation for her hearing, a great deal of time had been spent with her. From our perspective, if one word (more than any other) could be used to characterize this woman's demeanour, it would be "frightened." This view was corroborated by the psychologist who had examined our client. According to her, this claimant was one of the most traumatized people she had ever encountered in years of practice.

It was therefore surprising to read in the RPD's decision that the panel found this claimant to be lacking in subjective fear. This was because her failure to claim asylum in the United States, when she had the opportunity to do so, was found to be behaviour inconsistent with someone who is truly afraid.

It is not uncommon, of course, for RPD panels to determine that a claimant is lacking in subjective fear. In Canada v. Ward, the Supreme Court of Canada affirmed that there is a bipartite test for persecution: a claimant must subjectively fear persecution, and this fear must be well-founded in an objective sense. ${ }^{8}$ La Forest J., writing for the Court, cited the oft-quoted passage of Heald J.A. in the Federal Court of Appeal decision in Rajudeen:

The subjective component relates to the existence of the fear of persecution in the mind of the refugee. The objective component requires that the refugee's fear be evaluated objectively to determine if there is a valid basis for that fear. ${ }^{9}$

The subjective component of the bipartite test has engendered both controversy and questions. Is it appropriate for board members to delve into whether fear actually exists in the minds of refugee claimants? If so, should the subjective and objective components be weighted equally? Could the lack of subjective fear negate a refugee claim, even if there are objective reasons for the claimant to fear persecution? If so, should it?

It is timely to consider the status of "subjective fear" in refugee determinations in view of the addition of "consolidated grounds" for protection found in the Immigration and Refugee Protection Act (IRPA). ${ }^{10}$ Section 97 of IRPA introduces the term "persons in need of protection," and the court has already addressed whether such persons must demonstrate a subjective fear of persecution in order to qualify for "protected person" status.

Looking at the issue of subjective fear from historical, psychological, and legal perspectives, we argue that: (a) the drafters of the UN Convention never intended claimants to be "subjectively afraid" in order to qualify for protection; (b) determining an asylum seeker's state of mind presents a minefield of potential problems for decision makers; and (c) given the new IRPA provisions dealing with persons in need of protection, the question is not whether there is a bipartite test for determining well-founded fear, but whether, indeed, there ought to be.

\section{History}

One may begin by asking, "where does the notion arise that refugee status is determined, in part, by a person's frame of mind?" Where does it say that a person must actually be afraid in order to qualify as a Convention refugee? The Convention itself stipulates that a person's unwillingness to avail himself of the protection of his country must be "owing to a well-founded fear of being persecuted." ${ }^{11}$ It does not specify, however, whether "fear" is meant to be "[t]he emotion of pain or uneasiness caused by the sense of impending danger or by the prospect of some possible evil," or "a particular apprehension of some future evil," or "an apprehension or dread of something that will or may happen in the future" - all definitions found in the Oxford English Dictionary. ${ }^{12}$ 
Support for the first definition of "fear" is found in the Handbook on Procedures and Criteria for Determining Refugee Status, published in 1988 by the United Nations High Commissioner for Refugees. It states, at paragraph 38 :

To the element of fear - a state of mind and a subjective condition - is added the qualification "well-founded". This implies that it is not only the frame of mind of the person concerned that determines his refugee status, but that this frame of mind must be supported by an objective situation. The term "well-founded fear" therefore contains a subjective and an objective element, and in determining whether well-founded fear exists, both elements must be taken into consideration. ${ }^{13}$

In his book The Law of Refugee Status, James Hathaway argues that this two-pronged, bipartite approach to the definition of "well-founded fear" is "neither historically defensible nor practically meaningful." ${ }^{14}$ According to Professor Hathaway, "[w] ell founded fear has nothing to do with the state of mind of the applicant for refugee status, except insofar as the claimant's testimony may provide some evidence of the state of affairs in her home country." 15

One reason why decision makers and commentators have found it necessary to examine the psychological reaction of claimants to conditions in their state of origin, states Hathaway, is the linguistic ambiguity of the word "fear." He writes:

While the word "fear" may imply a form of emotional response, it may also be used to signal an anticipatory appraisal of risk. That is, a person may fear a particular event in the sense that she apprehends that it may occur, yet she may or may not (depending on her personality and emotional make-up) stand in trepidation of it actually taking place. It is clear from an examination of the drafting history of the Convention that the term "fear" was employed to mandate a forward-looking assessment of risk, not to require an examination of the emotional reaction of the claimant. ${ }^{16}$

The predecessor to the UN Convention definition of "refugee" can be found in the Constitution of the International Refugee Organization (IRO). The IRO was the first to incorporate the word "fear" into its definition of a refugee. As explained by Guy Goodwin-Gill in his text The Refugee in International Law, the word was used not to express an emotion, but rather a desire not to be returned to a country where persecution was a reasonable possibility. He writes:

[T] he IRO Constitution included as refugees those unable or unwilling to avail themselves of the protection of the government of their country of nationality or former residence. It was expressly recognized that individuals might have 'valid objections' to returning to their country of origin, including 'persecution or fear based on reasonable grounds of persecution because of race, religion, nationality or political opinions,' and objections 'of a political nature judged by the IRO to be valid'. ${ }^{17}$

Hathaway argues that the inclusion of the word "fear" in the IRO Constitution was meant to extend protection beyond those who had been persecuted in the past. It allowed for protection to be granted to those who, even though not persecuted in the past, might still be in jeopardy in their state of origin because of who they were or what they believed. "The establishment of the alternative formulation of refugee status was thus intended to recognize the importance not only of sheltering those who had already been persecuted, but equally of extending protection to those who could be spared from prospective harm." ${ }^{18}$ Concludes the author: "The use of the term 'fear' was intended to emphasize the forward-looking nature of the test, and not to ground refugee status in an assessment of the refugee claimant's state of mind." 19

According to Hathaway, a claimant's state of mind was meant to be relevant only in exceptional cases, of persons who had suffered past persecution, or whose "horrifying memories made it impossible for them to consider returning." ${ }^{20}$ The example given was of a person who had fled Nazi Germany and for psychological reasons could not return after the war, even though, objectively, there was no longer a risk of persecution. This exception is found in the current legislation at subsection $108(4) .{ }^{21}$ Where the reasons for which persons sought refugee protection have ceased to exist, they may still be Convention refugees or persons in need of protection if able to establish that there are "compelling reasons" arising out of previous persecution for refusing to avail themselves of the protection of their country. ${ }^{22}$ In all other cases, argues Hathaway, whether fear actually exists in a claimant's mind is irrelevant.

Atle Grahl-Madsen, in The Status of Refugees in International Law, takes a similar view of the propriety of peering into the minds of refugee claimants. "The adjective 'wellfounded'," he states, "suggests that it is not the frame of mind of the person concerned which is decisive for his claim to refugeehood, but that this claim should be measured with a more objective yardstick." ${ }^{23}$ According to Grahl-Madsen:

[T] he frame of mind of the individual hardly matters at all. Every person claiming - or being claimed (in the case of minors) - to be a refugee has "fear" ("well-founded" or otherwise) of being persecuted in the sense of the present provision, irrespective of whether he jitters at the very thought of his return to his 
home country, is prepared to brave all hazards, or is simply apathetic or even unconscious of the possible dangers. ${ }^{24}$

Clearly a fearful state of mind on the part of the refugee claimant, on its own, is not enough to satisfy the Convention refugee definition. There must be an objective basis to that fear. By the same token, the mere fact that human rights violations are prevalent in an asylum-seeker's country is insufficient evidence to justify a positive determination. The individual's particular circumstances must be placed in the context of those violations to show that he or she would be at risk if returned there.

To Grahl-Madsen, the "subjective" aspect of the refugee definition referred to those individual circumstances, or characteristics, of the claimant. The problem with trying to determine whether fear actually exists in a person's psyche, he states, is that

[w] cannot find a meaningful, common denominator in the minds of refugees. We must [therefore] seek it in the conditions prevailing in the country whence they have fled. "Well-founded fear of being persecuted" may therefore be said to exist, if it is likely that the [individual] person concerned will become the victim of persecution if he returns to his country of origin. ${ }^{25}$

Implied in the last sentence is the phrase "regardless of his or her state of mind."

\section{Psychology}

To determine whether a refugee claimant subjectively fears persecution, the Supreme Court of Canada in Ward explained that a decision maker must establish whether such a fear exists "in the mind of the refugee." ${ }^{26}$ Yet, as GoodwinGill points out: "Fear, and the degree to which it is felt by a particular individual, are incapable of precise quantification." ${ }^{27}$

Since IRB members are not capable of actually reading a person's mind, the existence of subjective fear, or the lack thereof, is determined through an examination of a claimant's actions and statements.

Typically, the Board finds that a refugee claimant lacks subjective fear when that person's actions do not conform to what is perceived to be the expected behaviour of someone who is afraid. Board members assume, for example, that persons who truly fear persecution will leave their country at the earliest opportunity. They will seek asylum in the first country where such a claim is possible, they will not return voluntarily once having left the country where they fear persecution, and they will ask for refugee status at the Canadian port of entry or as soon as possible after entering Canada. Unless they are able to provide a reasonable explanation for their behaviour, those who act differ- ently are routinely found by the Board to be lacking a subjective fear of persecution. ${ }^{28}$

Such decisions are based on the member's understanding of human behaviour. They are premised on the notion that, normally, people who are afraid will act in certain predictable ways. This approach, however, is fraught with potential problems - especially in a refugee context.

The first concern arises from the fact that not all individuals react to fear or danger in the same way. Although it is true, as Eve Carlson notes in her text Trauma Assessments: A Clinician's Guide, that “[w]hen humans are exposed to extreme danger, they have a natural response of fear and anxiety," ${ }^{29}$ how the trauma that arises from fear will manifest itself varies from person to person.

The clearest psychological indicators that someone has been exposed to extreme danger are the symptoms attributed to Post-Traumatic Stress Disorder (PTSD). PTSD is associated with victims of the types of persecution regularly found in refugee claims: assault; detention; kidnapping; torture (both physical and psychological); and rape and other kinds of sexual assault. However, as Carlson points out,

...although all of the core, secondary and associated trauma symptoms can occur as part of a post-traumatic disorder, all of these will not necessarily occur. Different symptoms may predominate in a client's symptom picture as a result of the influence of various individual and situational factors and the length of time that has passed since the trauma. ${ }^{30}$

In short, people react to fear in individualized ways. As such, predicting how a person will respond to danger or fear is at best an extremely challenging task, particularly for those not trained in the psychology of trauma.

Added to the complexity of assessing fear is the notion that culture may be a factor in how a person responds to danger. As Carlson observes:

It is possible that "particular symptoms may predominate in a traumatized individual as a result of cultural influences. As with all psychological disorders, we should expect culture to greatly influence how symptoms are expressed. Although the bulk of research and clinical reports relating to trauma responses has focused on white, middle and upper-middle class Americans, the research on trauma responses of persons from other cultures (and U.S. subcultures) that is available indicates that there may be considerable variation in the symptoms observed following trauma in different cultures." 31

This is not to say that people from different cultures have a different internal response to trauma, only that the manifestation of those symptoms may differ according to one's 
culture. In other words, persons from different cultures may appear, to a western observer, to respond to trauma in an "atypical" way. This cross-cultural phenomenon ought to be a warning sign to RPD members who are drawing conclusions about subjective fear based on the behaviour of people coming from a myriad of cultures.

One factor that may also affect the assessment of subjective fear is the claimant's gender. Elizabeth Adjin-Tettey has argued that the subjective fear component of the bipartite test has a particularly negative impact on female claimants. She notes that

$[w]$ omen fleeing gender-related harms have often not been successful in communicating their subjective fear of persecution even in the face of strong objective indicators because they have difficulty relating their claims. In particular, female refugee claimants are often reluctant to disclose experiences of sexual violence to asylum decision-makers who are predominantly men, because of the stigma attached to sexual violence, or due to trauma. ${ }^{32}$

The fact that much testimony will be relayed to the Board via interpreters, she suggests, may result in testimony that is either distorted, censored, or both.

One assumes that a person acting rationally would leave a situation of risk as soon as possible. Similarly, it would be rational for a person at risk to seek protection at the earliest opportunity. However, even a cursory survey of psychological texts on the subject of trauma makes it clear that people who have been traumatized do not always act rationally, let alone in their own best interests. People who are afraid, especially those who have been traumatized by events, often act in ways that seem irrational and counterintuitive. This does not mean they have not been traumatized or that they are not truly afraid. In fact, the very opposite may be true.

Instead of escaping, seeking protection, or other behaviour that one would normally associate with a profound fear, the traumatized person may instead become dissociated from her reality. According to numerous studies, "dissociation is an integral aspect of PTSD." ${ }^{33}$ In her authoritative text, Trauma and Recovery, Dr. Judith Herman explains:

[a person suffering from PTSD] may feel as though the event is not happening to her, as though she is observing from outside her body, or as though the whole experience is a bad dream from which she will shortly awaken. These perceptual changes combine with a feeling of indifference, emotional detachment, and profound passivity in which the person relinquishes all initiative and struggle. ${ }^{34}$
People caught in situations that seem inescapable may respond, not by taking steps to escape, but by removing themselves from danger in a psychological sense only. Writes Dr. Herman:

When a person is completely powerless, and any form of resistance is futile, she may go into a state of surrender. The system of self-defence shuts down entirely. The helpless person escapes from her situation not by action in the real world but rather by altering her state of consciousness." (emphasis added) ${ }^{35}$

A state of profound passivity, in which one relinquishes all initiative and struggle, is not one that leads to the type of actions the IRB typically associates with a genuine subjective fear. Yet these are the actions - or in-actions - of people who are afraid. As Dr. Herman explains: "The constrictive symptoms of the traumatic neurosis apply not only to thought, memory, and states of consciousness but also to the entire field of purposeful action and initiative."36

Sometimes, trauma prevents individuals from expressing or proclaiming their fear, the very act that Board members seem to believe is consistent with a "subjective fear." In fact, writes Bessel A. van der Kolk, "trauma may lead to a 'speechless terror', which in some individuals interferes with the ability to put feelings into words, leaving emotions to be mutely expressed by dysfunction of the body." ${ }^{37}$

Other psychological phenomena associated with trauma suggest additional reasons why traumatized individuals may not react in anticipated ways to situations of risk. Everstine and Everstine, in their text The Trauma Response, note that:

[s] ome victims [of trauma], particularly those who were seriously injured, have no memory of the event. This may be due to physical trauma (i.e. head injury), emotional trauma or both. Some may eventually remember what happened to them, while others may never experience the memory. ${ }^{38}$

It is true that in assessing subjective fear, Board members may be aware of the complexities of trauma, or psychological reports filed as evidence may alert them to the claimant's state of mind. But, as the case described in the Introduction illustrates, a diagnosis of PTSD does not prevent conclusions about subjective fear from being made based on the assumed behaviour of persons who are afraid. Moreover, with single-member panels, the high cost of psychologi$\mathrm{cal} /$ psychiatric reports, the scarcity of legal aid funding for refugee claimants, and the significant incidence of claimants appearing without counsel, ${ }^{39}$ there is a strong likelihood that "mis-diagnoses" will be made in determining the existence of subjective fear. 
Finally on this point, it should be noted that other motivations, apart from or in addition to fear, may also influence a claimant's behaviour. The Federal Court has held that negative inferences about subjective fear should not be drawn if a refugee claimant offers a reasonable explanation for failure to seek asylum in a transit country. ${ }^{40}$ The presence of family members in the country of destination, for example, has been held to be a justifiable reason for failure to make a claim while en route to Canada. ${ }^{41}$ Similarly, people may decide not to flee a situation of danger out of concern for dependents, or because the risk of flight may seem greater than the risk of staying put, because the cost of fleeing is too dear, or for a variety of other reasons. Although matters such as delay in departure, return to the country of origin, or failure to claim at the first opportunity may be applied appropriately to the question of objective risk, none of them necessarily negates a subjective fear of persecution.

People who may fear the consequences of their actions nonetheless speak out, write articles, and take political action in the face of brutal repression as a matter of principle or conscience. The prisons and torture chambers around the world are filled with such people. The point is that people react to danger, and to fear, in a myriad of ways, and for a wide variety of reasons. Their actions are not necessarily driven predominantly by fear, even though they may have great reason to be fearful. Conclusions on what is in the mind of such people, therefore, should not be made lightly.

\section{The Law}

\section{A. Ward and Rajudeen}

The Supreme Court of Canada's decision in Ward is often cited as the leading authority for the proposition that refugee claimants are required to establish a subjective fear of persecution. Ward, however, contains very little, if any, analysis of why this is so. As La Forest J. acknowledges, "[I]n the present case, the only real issue is the objective test." 42 The issues before the Court in Ward were: persecution and state complicity; the meaning of "membership in a particular social group;" the meaning of "political opinion;" the effect of section 15 of the Charter on the definition of Convention refugee; and the burden of proof for persons holding dual nationality. ${ }^{43}$

In Ward, the Court made brief mention of the fact that subjective fear is a necessary component of the Convention refugee definition. The Court simply adopted the test articulated and applied by Heald J.A. in Rajudeen. ${ }^{44}$

Curiously, although Rajudeen has become the standard authority for the bipartite test, the case is not really about the bipartite nature of "well-founded fear," let alone the subjective component of the test. Rajudeen concerned a Sri Lankan Tamil who was threatened and beaten by the Sinhalese "thugs" on a number of occasions. The Sri Lankan police, meanwhile, turned a blind eye to the communal violence directed at Tamils.

In Rajudeen, the Immigration Appeal Board determined the claimant not to be a Convention refugee for the following reasons:

Whether events in Sri Lanka can be classed as "civil war" or not, there is certainly civil unrest but the nature of that unrest and the resulting harassment of Mr. Rajudeen is not such that he can be classed as a Convention refugee. ${ }^{45}$

The primary focus of Heald J.A., in his reasons, was the meaning of "persecution." Citing definitions for "persecute" and "persecution" found in The Living Webster Encyclopedic Dictionary and The Shorter Oxford English Dictionary respectively, Justice Heald concluded that " $[\mathrm{b}]$ ased on the evidence of this case, it is clear to me that this applicant was persecuted over a lengthy period of time in Sri Lanka because of his religious beliefs as well as his race." 46

The other issue before the Court in Rajudeen was whether, in the circumstances, the claimant was required to avail himself of the protection of the Sri Lankan authorities. On the evidence, the Court held that Mr. Rajudeen had "ample justification" for being unwilling to do so. ${ }^{47}$

Heald J.A. concluded his reasons by stating: "I accordingly conclude, that on the basis of all the evidence adduced, it was possible for the Board to come to only one conclusion, namely, that this applicant had satisfied the definition of Convention refugee as contained in the Immigration Act, 1976." The other members of the panel concurred with this disposition. ${ }^{48}$

What is curious about the decision in Rajudeen is that the claimant displayed many of the qualities of an individual typically found by the IRB to be lacking in subjective fear. Although being beaten in January, March, April, and August 1978, Mr. Rajudeen did not leave Sri Lanka until January $1979 .{ }^{49}$ He went to India and then Pakistan, but did not claim asylum. He took a job as a seaman, travelling to various places in Europe, South America, and Asia over a period of more than two years. He failed to make a refugee claim in any country to which he travelled during this period. ${ }^{50}$ In November 1981, while his ship was docked in Karachi, Pakistan, Mr. Rajudeen made the decision to return voluntarily to Sri Lanka, believing that "neither India nor Pakistan accepted refugees." ${ }^{51}$ There, he again experienced harassment by the Sinhalese. Nevertheless, he remained in the country until March 1982. He flew to Japan 
where he joined the crew of a Greek ship. He did not claim asylum in Japan, but when the ship docked in Vancouver, Mr. Rajudeen finally made a claim to refugee status. ${ }^{52}$

Mr. Rajudeen had lingered in his country long after claiming to experience harassment, beatings, and threats, had failed to make claims in numerous countries when he had the opportunity to do so, and had returned to Sri Lanka voluntarily. All of these are factors routinely cited by Boards in support of findings that claimants are lacking a subjective fear. Nevertheless, the Federal Court of Appeal had no hesitation in finding that this claimant had met the definition of Convention refugee. It is interesting, then, that this is the leading judicial authority for the proposition that subjective fear is a necessary component of the refugee definition.

\section{B. Yusufv. Kamana/Tabet-Zatla}

Although consistently accepting that there is a bipartite test for refugee determination, Canadian courts have not all been of the view that the two components of the test should be given equal weight. In Yusuf v. Canada (M.E.I. $)^{53} \mathrm{Mr}$. Justice Hugessen, then of the Federal Court of Appeal, questioned the propriety of rejecting a claim for which there was an objective basis for the claimant's fear, on account of a lack of subjective fear. Wrote Hugessen J.:

It is true, of course, that the definition of a Convention refugee has always been interpreted as including a subjective and an objective aspect. The value of this dichotomy lies in the fact that a person may often subjectively fear persecution while that fear is not supported by fact, that is, it is objectively groundless. However, the reverse is much more doubtful. I find it hard to see in what circumstances it could be said that a person who, we must not forget, is by definition claiming refugee status could be right in fearing persecution and still be rejected because it is said that fear does not actually exist in his conscience. The definition of a refugee is certainly not designed to exclude brave or simply stupid persons in favour of those who are more timid or more intelligent. ${ }^{54}$

The reasoning of Hugessen J. in Yusuf has not been universally accepted by the Federal Court. It was followed in a 2003 decision, Balendra v. Canada (M.C.I.). ${ }^{55}$ It was also followed in a 1999 decision, Uthayukumar v. Canada (M.C.I), where Justice Blais cited the IRB's Guidelines on Procedural and Evidentiary Issues for Child Refugee Claimants, which states that "a child claimant may not be able to express a subjective fear of persecution in the same manner as an adult claimant." ${ }^{56}$

Other decisions have distinguished Yusuf on the basis that it was decided before the Supreme Court of Canada decision in Ward. This was the case in Maqdassy v. Canada (M.C.I. ), ${ }^{57}$ where the applicant, citing Yusuf, submitted that it may not be necessary to establish a subjective fear of persecution where it has been clearly shown that an objective basis for the fear exists. In rejecting this argument, Madame Justice Tremblay-Lamer referred to her earlier decision in Tabet-Zatla v. Canada (M.C.I. $)^{58}$ where, citing her even earlier decision in Kamana, she held that the lack of evidence going to the subjective element of the claim is in itself sufficient for the applicant's claim to fail. In Kamana v. Canada (M.C.I.), Tremblay-Lamer J. wrote:

The lack of evidence going to the subjective element of the claim is a fatal flaw which in and of itself warrants dismissal of the claim, since both elements of the refugee definition - subjective and objective - must be met. ${ }^{59}$

A number of other Trial Division decisions have followed Kamana and Tabet-Zatla, including Fernando $v$. Canada (M.C.I. ${ }^{60}$ and Anandasivam v. Canada (M.C.I.), ${ }^{61}$ two judgments from 2001.

Strictly speaking, the Kamana/Tabet-Zatla interpretation of what the Supreme Court said in Ward cannot be challenged. By definition, under a bipartite test, both parts of the equation must be established. The potential consequence of this line of reasoning are Yusuf-like decisions, where a refugee claim is rejected due to a lack of subjective fear in spite of evidence that establishes an objective ground for the claimant to be afraid of returning home.

Hathaway has criticized this approach to refugee determination. He writes:

[I]t would be anomalous to define international legal obligations in such a way that persons facing the same harm would receive differential protection. Why should states be expected to distinguish among persons similarly at risk on the basis of variations of individual temperament or tolerance? Why should an individual of stoic disposition be viewed as less worthy of protection than one who is easily scared, or who proclaims her concerns with great fervour? Yet surely this is the implication of giving "substantial, if not primary weight to a claimant's own assessment of his or her own situation."

Logic dictates that since the central issue is whether or not an individual can safely return to her state, the claimant's anxiety level is simply not a relevant consideration. ${ }^{62}$

Another potential consequence of the reasoning in Kamana/Tabet-Zatla is that the Board, after finding that the subjective fear component of the test has not been met, could simply decide not to examine whether the fear is 
objectively well-founded. Indeed, as Justice Lemieux stated in Anandasivam, "lack of subjective fear constitutes a critical barrier to a refugee claim which, on its own, justifies non recognition." ${ }^{63}$ If one aspect of the test is not met, what is the point of examining the other aspect?

One can legitimately question how this interpretation of the refugee definition can be reconciled with La Forest J's statement in Ward that, clearly, "the lynch-pin of the analysis [of the test for determining fear of persecution] is the state's inability to protect." ${ }^{\prime 4}$ Following the reasoning in Kamana/Tabet-Zatla, persons found lacking in subjective fear may still be at risk due to their country's inability, or unwillingness, to protect. They may still face persecution. Indeed, how is such an interpretation consistent with one of the stated objectives of the Immigration and Refugee Protection Act, "to recognize that the refugee program is in the first instance about saving lives and offering protection to the displaced and persecuted"?65

\section{Section 97 of the IRPA}

Thrown into this mix is section 97 of the IRPA. Section 95 of the Act states that: "Refugee protection is conferred on a person when ... (b) the Board determines the person to be a Convention refugee or a person in need of protection." "Person in need of protection" is defined in section 97 as:

a person in Canada whose removal to their country or countries of nationality or, if they do not have a country of nationality, their country of former habitual residence, would subject them personally

(a) to a danger, believed on substantial grounds to exist, of torture within the meaning of Article 1 of the Convention Against Torture; or

(b) to a risk to their life or to a risk of cruel and unusual treatment or punishment.

In a number of recent decisions, the Federal Court has held that there is no subjective component to the test for determining a person in need of protection. In Shah v. Canada (M.C.I.) Justice Blanchard noted that the Board had appeared "to dismiss the claimant's s. 97 application based on a finding that the applicant's behaviour is not consistent with a well-founded fear of persecution." ${ }^{16} \mathrm{He}$ had delayed his departure from Pakistan until one and half years after incidents of harassment had begun. ${ }^{67}$ Blanchard J. decided that:

[e]ven if [he] were to accept this finding as reasonable... the test under s. 97 of the Act does not require a determination of subjective fear of persecution, but rather a determination that removal would subject an applicant to a danger of torture, or to a risk to life or to a risk of cruel and unusual treatment or punishment under certain conditions. ${ }^{68}$

Justice Blanchard's analysis of the test for s. 97 in Shah has been followed, most recently in the case of Ghasemian v. Canada (M.C.I.). ${ }^{69}$ In Bouaouni v. Canada (M.C.I.), ${ }^{70}$ a decision that post-dated Shah, the RPD did not believe the claimant's testimony that he had been beaten and tortured by the Tunisian police. On judicial review, Justice Blanchard discusses the different approaches to claims made under sections 96 (regarding Convention refugees) and 97 of the Act. Discussing how the Board should address claims under s. 97 of the IRPA, he states:

There may well be instances where a refugee claimant, whose identity is not disputed, is found to be not credible with respect to his subjective fear of persecution, but the country conditions are such that the claimant's particular circumstances, make $\mathrm{him} / \mathrm{her}$ a person in need of protection. It follows that a negative credibility determination, which may be determinative of a refugee claim under s. 96 of the Act, is not necessarily determinative of a claim under subsection 97 (1) of the Act. The elements required to establish a claim under section 97 differ from those required under section 96 of the Act where a wellfounded fear of persecution to a Convention ground must be established. Although the evidentiary basis may well be the same for both claims, it is essential that both claims be considered as separate. A claim under section 97 of the Act requires that the Board apply a different test, namely whether a claimant's removal would subject him personally to the dangers and risks stipulated in paragraphs 97 (1) (a) and (b) of the Act. ${ }^{71}$

The IRPA is a relatively new piece of legislation, and many more decisions on the evaluation of section 97 claims are to be expected. Still, in light of this jurisprudence, one can arguably say that a double standard exists for applicants before the Board. Those who face a risk to life, torture, or cruel and unusual treatment or punishment need not establish that they subjectively fear such treatment. Those who face other forms of persecution (for example, arbitrary detention, denial of the right to work and other forms of systematic discrimination, harassment, or physical treatment that does not amount to torture or cannot be considered "cruel and unusual") will have to establish subjective fear.

To illustrate the point, here is an example. Imagine that both claimants A and B have objectively well-founded reasons for not returning to their respective countries of origin. Claimant A will likely be sent to prison for years because of his political writings. Claimant $\mathrm{B}$, who is charged with theft, will likely be deprived of food and sleep, and held 
incommunicado for several months, because that is how persons charged with criminal offences are routinely treated in his country. Both claimants came to Canada via the Netherlands, but neither claimed asylum there. Both waited two weeks before initiating their claims in Canada. Claimant A, having to deal with the bipartite test under section 96 of the IRPA, may have his claim turned down due to a lack of subjective fear. In claimant B's case, under section 97, subjective fear will not even be an issue.

It is hard to discern any justification for requiring some claimants to meet a bipartite test of well-founded fear, but not others. All are seeking the same thing, protection from persecution. The only factors that distinguish claims made under section 96 and 97 are the necessity for the former to be based on one or more of the grounds enumerated in the Convention, and the limited form of persecution contemplated by section 97. As Blanchard J. suggests in Bouaouni, in many cases, the evidentiary base for both claims will be the same. Why then, with respect to the question of subjective fear, should some claims be treated differently than others?

\section{Conclusion}

It is perhaps an ideal time for Canadian decision makers to reconsider the appropriateness of the bipartite test for determining well-founded fear of persecution. The historical basis for the bipartite test has, for some years, been seriously questioned by academics. The equal division of weight between the subjective and objective components of the test continues to be challenged by some members of the judiciary. Moreover, given the current state of psychological research into Post-Traumatic Stress Disorder, one can confidently say now that many potential pitfalls exist for board members in determining whether subjective fear actually exists in the minds of claimants. Finally, due to the introduction of the category of "person in need of protection," there are now two standards of review for claimants, with no clear, logical reason for this to be so. Adopting a test that requires more attention to the objective nature of risk facing refugee claimants, and less on what may be going on in their minds, would place emphasis, quite properly in our view, on the need for protection.

\section{APPENDIX “A”}

\section{Failure to claim elsewhere:}

Saez v. Canada (Minister of Employment and Immigration), [1993] F.C.J. No. 631 (FCTD)*

Ilie v. Canada (Minister of Citizenship and Immigration), [1994] F.C.J. No. 1758 (FCTD)

Bogus v. Canada (Minister of Employment \& Immigration), [1994] F.C.J. No. 1455 (FCTD)

Lameen v. Canada (Secretary of State), [1994] F.C.J. No. 886 (FCTD)

Thandi v. Canada (Secretary of State), [1994] F.C.J. No. 819 (FCTD)

Hristov v. Canada (Minister of Employment and Immigration), [1995] F.C.J. No. 32 (FCTD)

Wey v. Canada (Secretary of State), [1995] F.C.J. No. 286 (FCTD)

Memarpour v. Canada (Minister of Citizenship and Immigration), [1995] F.C.J. No. 1679 (FCTD)

Hankali v. Canada (Minister of Citizenship and Immigration), [1996] F.C.J. No. 339 (FCTD)

\section{Delay in leaving country where persecution feared:}

Huerta v. Canada (Minister of Employment and Immigration), [1993] F.C.J. No. 271 (FCA)

Radulescu v. Canada (Minister of Employment and Immigration), [1993] F.C.J. No. 589 (FCTD)

Castillejos v. Canada (Minister of Citizenship and Immigration), [1994] F.C.J. No. 1956 (FCTD)

De Beltran v. Canada (Secretary of State), [1994] F.C.J. No. 1282 (FCTD)

Hristov v. Canada (Minister of Employment and Immigration), [1995] F.C.J. No. 32 (FCTD)

Al-Kahtani v. Canada (Minister of Citizenship and Immigration), [1996] F.C.J. No. 335 (FCTD)

Hankali v. Canada (Minister of Citizenship and Immigration), [1996] F.C.J. No. 339 (FCTD)

\section{Delay in claiming in Canada:}

Huerta v. Canada (Minister of Employment and Immigration), [1993] F.C.J. No. 271 (FCA)

Hanna v. Canada (Minister of Employment and Immigration), [1994] F.C.J. No. 133 (FCTD)

Ezi-Ashi v. Canada (Secretary of State), [1994] F.C.J. No. 401, (FCTD)

Marquez v. Canada (Minister of Employment and Immigration), [1994] F.C.J. No. 850 (FCTD)

Lameen v. Canada (Secretary of State), [1994] F.C.J. No. 886, (FCTD)

Thandi v. Canada (Secretary of State), [1994] F.C.J. No. 819, (FCTD)

Carranza-Gonzalez v. Canada (Minister of Employment and Immigration), [1994] F.C.J. No. 1628 (FCTD) 
Panta v. Canada (Minister of Citizenship and Immigration), [1995] F.C.J. No. 1789 (FCTD)

Hankali v. Canada (Minister of Citizenship and Immigration), [1996] F.C.J. No. 339 (FCTD)

\section{Reavailement:}

Caballero v. Canada (Minister of Employment and Immigration), [1993] F.C.J. No. 483 (FCTD)

Larue v. Canada (Minister of Employment and Immigration), [1993] F.C.J. No. 484 (FCTD)

Tejani v. Canada (Minister of Employment and Immigration), [1993] F.C.J. No. 528 (FCTD)

Zergani v. Canada (Minister of Employment and Immigration), [1994] F.C.J. No. 493 (FCTD)

Galdamez v. Canada (Minister of Employment and Immigration), [1994] F.C.J. No. 1983 (FCTD)

Bogus v. Canada (Minister of Employment \& Immigration), [1994] F.C.J. No. 1455 (FCTD)

Gabeyehu v. Canada (Minister of Citizenship and Immigration), [1995] F.C.J. No. 1493 (FCTD)

Ali v. Canada (Minister of Citizenship and Immigration), [1996] F.C.J. No. 558 (FCTD)

Al-Kahtani v. Canada (Minister of Citizenship and Immigration), [1996] F.C.J. No. 335 (FCTD)

* All cases are identified by their QuickLaw citations.

\section{Notes}

1. RPD File no. AA1-01365, decision dated November 18, 2003.

2. Ibid. at 1 .

3. Ibid. at 1 .

4. Ibid. at 1 .

5. Confidential report of Dr. Marta Young, dated March 21, 2003 , at 6. Dr. Young is a registered psychologist in Ontario. She has a Ph.D. in clinical psychology with a specialization in refugee adaptation. She is a full-time professor in the School of Psychology at the University of Ottawa. Her research, teaching, and clinical supervision foci are all in the area of cross-cultural psychology, particularly as it relates to immigrant and refugee issues.

6. Ibid. at 6 .

7. Ibid. at 6 .

8. Canada (Attorney General) v. Ward, [1993] 2 S.C.R. 689, at para. 47.

9. Rajudeen v. Canada (Minister of Employment and Immigration) (1984), 55 N.R. 129, at page 134, [1984] F.C.J. No. 601 $(\mathrm{QL})$, at 6.

10. Immigration and Refugee Protection Act, S.C. 2001, c. 27.

11. Convention relating to the Status of Refugees, 28 July 1951, 189 U.N.T.S. 150, at 137, Article 1 (A).

12. The Compact Edition of the Oxford English Dictionary (1971), at 114 .

13. United Nations High Commissioner for Refugees, Handbook on Procedures and Criteria for Determining Refugee Status (Geneva, January 1988) at 11-12.
14. James C. Hathaway, The Law of Refugee Status (Toronto: Butterworths, 1991) at 65 .

15. Ibid. at 65, citing K. Petrini, "Basing Asylum Claims on a Fear of Persecution Arising from a Prior Asylum Claim" (1981), 56 Notre Dame Lawyer 719, at 724.

16. Ibid. at 66 .

17. Guy S. Goodwin-Gill, The Refugee in International Law ( Oxford: Clarendon Press, 1983) at 4

18. Supra note 14 at 67.

19. Ibid. at 69.

20. Ibid. at 68 , citing the Statement of Mr. Robinson of Israel, U.N. Doc. E/AC.32/SR.18, at 4, February 8, 1950.

21. Note that the "compelling reasons" exception, although codified in Canadian law, is limited in international law to Article 1 (A) (1) of the Convention - that is, pre-Second World War refugees. The UNHCR has argued that the exception extends to modern refugees. In 2002, however, the UK Court of Appeal rejected that interpretation in Hoxha v. Secretary of State for the Home Department, [2002] All ER 182, [2002] E.W.J. No. 4398 (QL).

22. Immigration and Refugee Protection Act, S.C. 2001 , c. 27 , s. 108 (4).

23. Atle Grahl-Madsen, The Status of Refugees in International Law, Vol. 1. (Leyden: A.W. Sijthoff, 1966) at 173.

24. Ibid. at 174.

25. Ibid. at 175.

26. Supra note 8 at para. 47.

27. Supra note 17 at 25 .

28. A list of Federal Court decisions dealing with IRB decisions where the Board made such findings regarding the lack of subjective fear can be found at Appendix A to this paper. The list is not meant to be exhaustive, merely illustrative of the type of reasoning often applied by the Board to this issue.

29. Eve B. Carlson, Trauma Assessments: A Clinician's Guide (New York: Guilford Press, 1997) at 39.

30. Ibid. at 39 .

31. Ibid., citing the study of Marsalla, Friedman, Gerrity, \& Scurfield, 1996, at 44

32. Elizabeth Adjin-Tettey, "Reconsidering the Criteria for Assessing Well-Founded Fear in Refugee Law" (1997) 25 Manitoba Law Journal 127 at para. 14.

33. Bessel A. van der Kolk, "The Complexity of Adaptation to Trauma: Self-Regulation Stimulus Discrimination, and Characterological Development" in van der Kolk, McFarlane, and Weisaeth. Traumatic Stress: The Effects of Overwhelming Experience on Mind, Body, and Society (New York: Guilford Press, 1996) at 192.

34. Judith Herman, M.D., Trauma and Recovery (New York: Basic Books, 1992, 1997) at 42.

35. Ibid. at 43 .

36. Ibid. at 46 .

37. Supra note 33 at 193.

38. Diana Sullivan Everstine and Louis Everstine, The Trauma Response: Treatment for Emotional Injury (New York. London: W.W. Norton, 1993) at 17. 
39. Currently, this figure is roughly 10 per cent to 12 per cent of claimants appearing before the RPD. It varies from province to province. In some provinces, the incidence of unrepresented claimants is almost 100 per cent. This information was taken from communications with Paul Aterman, acting general counsel for the Immigration and Refugee Board.

40. Hue v. Canada (Minister of Citizenship and Immigration) [1998] F.C. J. No. 283 (FCA) (QL).

41. El-Naem v. Canada (Minister of Citizenship and Immigration) [1997] F.C.J. No. 185 (FCTD) (QL), at para. 20.

42. Supra note 8 at para. 47.

43. Ibid. at para. 17.

44. The bipartite test set out in Rajudeen was confirmed again by the Supreme Court of Canada in Chan v. Canada (Minister of Employment and Immigration), [1995] 3 S.C.R. 593 (SCC), at para. 119.

45. Supra note 9 at 6 (QL).

46. Ibid. at 6 (QL).

47. Ibid. at $7(\mathrm{QL})$.

48. In concurring reasons, Stone J. addressed the issue of state complicity in the attacks on Mr. Rajudeen.

49. Supra note 9 at 2, 3, 4 (QL).

50. Ibid. at $4(\mathrm{QL})$.

51. Ibid. at $4(\mathrm{QL})$.

52. Ibid. at 4, 5 (QL).

53. Yusuf v. Canada (Minister of Employment and Immigration) [1992] 1 F.C. 629, [1991] F.C.J. No. 1049 (FCA) (QL).

54. Ibid. at para. 5 .

55. Balendra v. Canada (Minister of Citizenship and Immigration) 2003 F.C. 1078, [2003] F.C.J. No. 1352 (FCTD) (QL), at para. 11.

56. Uthayakumar v. Canada (Minister of Citizenship and Immigration) [1999] F.C.J. No. 1013 (FCTD) (QL), at para. 23.

57. Maqdassy v. Canada (Minister of Citizenship and Immigration), [2002] F.C.J. No. 238 (FCTD) (QL).

58. Tabet-Zatla v. Canada (Minister of Citizenship and Immigration) [1999] F.C.J. No. 1778 (FCTD) (QL).

59. Kamana v. Canada (Minister of Citizenship and Immigration) [1999] F.C.J. No. 1695 (FCTD) (QL), at para. 10.

60. Fernando v. Canada (Minister of Citizenship and Immigration) [2001] F.C.J. No. 1129 (FCTD) (QL), at para. 2.

61. Anandasivam v. Canada (Minister of Citizenship and Immigration) [2001] F.C.J. No. 1519 (FCTD) (QL), at para. 23.

62. Supra note 14 at 69-70.

63. Supra note 61 at para. 23.

64. Supra note 8 at para. 45.

65. Immigration and Refugee Protection Act, s. 3 (2) (a).

66. Shah v. Canada (Minister of Citizenship and Immigration) [2003] F.C.J. No. 1418 (FCTD) (QL), at para. 16.

67. Ibid. at para. 7 .

68. Ibid. at para. 16 .

69. Ghasemian v. Canada (Minister of Citizenship and Immigration) F.C.J. No. 1591 (FCTD) (QL), at paras. 18-19.

70. Bouaouni v. Canada (Minister of Citizenship and Immigration) F.C.J. No. 1540 (FCTD) (QL).

71. Ibid. at para. 41.
The authors are lawyers at Community Legal Services (Ottawa-Centre) in Ottawa, Ontario, Canada. Mr. Bossin, who also teaches immigration law at the University of Ottawa, Faculty of Common Law, wrote the paper, while Ms. Demirdache conducted the primary legal research. Both wish to acknowledge the assistance of Dr. Marta Young of the University of Ottawa School of Psychology regarding psychological texts on trauma. 